\title{
ANALISIS PENERAPAN SISTEM AKUNTANSI MANAJEMEN TERHADAP PEGENDALIAN KUALITAS PRODUK DI PT.EMPAT SAUDARA MANADO
}

\author{
Janrilius Doli Butarbutar ${ }^{1}$, Herman Karamoy $^{2}$, Victorina Z.Tirayoh ${ }^{3}$ \\ ${ }^{123}$ Fakultas Ekonomi dan Bisnis, Jurusan Akuntansi, Universitas Sam Ratulangi, Jl.Kampus Bahu, Manado, \\ 95115, Indonesia
}

E-mail : Janriliusbutarbutar@yahoo.com

\begin{abstract}
The development of management accounting system is now very rapid. Company managers require management information systems to implement planning, control and decisionmaking functions. Management accounting systems are systems that collect operational and financial data, process, store and report to users, ie workers, managers, and executives. The purpose of this research is to know the application of management accounting system to product quality control at PT.Empat Saudara Manado. The method used is descriptive qualitative. The results of the application of management accounting system in PT.Ampat Saudara manado has shown its role as a tool in controlling product quality, and can help managers to be better prepared in facing company problems and control product quality. PT.Empat Saudara manado only need to maintain it so that in megontrol every part there is no errorsin every running process.
\end{abstract}

Keywords: management accounting system, Product Quality Control, SAM Characteristics.

\section{PENDAHULUAN}

\subsection{Latar Belakang}

Perkembangan sistem akuntansi manajemen saat ini sudah sangat pesat. Manajermanajer perusahaan memerlukan sistem akuntansi manajemen dalam melaksanakan fungsifungsi perencanaan, pengendalian dan pengambilan keputusan. Sistem akuntansi manajemen yang terdapat dalam suatu perusahaan pada dasarnya memiliki tiga tujuan utama yaitu: penyediaan informasi untuk penentuan harga pokok barang/ jasa, penyediaan informasi untuk perencanaan, pengendalian, evaluasi dan perbaikan berkesinambungan, serta memberikan informasi untuk pengambilan keputusan. Manajemen memerlukan sistem evaluasi kinerja yang dapat membantu dalam mengevaluasi prestasi kinerja perusahaan melalui kinerja manajer pada berbagai tingkat pusat pertanggungjawaban (Endang Raino Wirjono, 2013).

Dalam pengendalian mutu (quality control) menjalankan serangkaian proses dimana produk diperiksa dan dievaluasi untuk meminimalkan terjadinya produk cacat atau rusak, setelah itu produk harus dibandingkan dengan kebutuhan dan keinginan pelanggan. Perubahan yang terjadi dalam dunia bisnis seperti teknologi informasi, teknologi produksi dan struktur organisasi mengakibatkan organisasi terus berkembang untuk mencapai tujuan organisasi di tengah persaingan bisnis yang semakin kompetitif (Siti Alliyah, 2015).

Perusahaan mendesain sistem akuntansi manajemen dalam membantu organisasi yang bersangkutan melalui para manejernya, yaitu dalam perencanaan, pengorganisasian, pengarahan dan pengambilan keputusan (Yuwinda Lempas,2014) .Aktifitas para manajer membutuhkan dukungan informasi. Sistem akuntansi manajemen merupakan sistem formal yang dirancang untuk menyediakan informasi bagi manajer. Perencanaan sistem akuntansi manajemen yang merupakan bagian dari sistem pengendalian organisasi perlu mendapat perhatian, hingga dapat diterapkan akan memberikan kontribusi positif dalam mendukung keberhasilan sistem pengendalian manajemen. Peningkatan kinerja manejerial diharapkan akan meningkatkan kinerja perusahaan. Informasi sangat berguna bagi perusahaan dalam 
kegiatan perencanaan, kontrol, dan pengambilan suatu perusahaan akan tergantung pada faktor struktur organisasi perusahaaan.

Jika dihubungkan peranan akuntansi dengan manajemen“ dalam Pengambilan Keputusan Manajerial" saja diharapkan tentu dapat membantu Manajer dalam membuat keputusan-keputusan khusus manajemen. Para manajer adalah orang yang ditunjuk pemilik perusahaan atau pemegang saham untuk menjalankan roda perusahaan dengan baik dan benar. Akuntansi Manejemen adalah suatu bidang ilmu akuntansi yang akan membantu para manajer dalam membuat skenario atau rekayasa dalam mengambil keputusan taktis yang akan diambil manajemen. Umpamanya: keputusan menerima atau menolak pesanan khusus, keputusan pembelian atau pembuatan komponen produk, keputusan penyewaan atau pengunaan sebagian kapasitas, keputusan meneruskan atau penghentian penjualan kelompok produk tertentu dan keputusan untuk menutup usaha untuk sementara, apakah suatu lini produk akan ditutup atau tidak, atau dalam pemilihan investasi apakah akan membeli mesin baru atau memperbaiki mesin lama. Keberhasilan suatu organisasi bisnis diera yang sarat dengan persaingan tergantung dari kesiapan suatu perusahaan dalam mengahadapi tantangan dan ancaman yang timbul yaitu dengan mengetahui informasi manajemen perusahaan (Octavia Ferona Ingkiriwang, 2013). Orang yang tidak terencana berfikir pendek dan mencari yang serba instan dan mencari produk yang bisa memberi keuntungan jangka pendek untuk menyelesaikan masalah yang ada di depan mata saja (Vita Dhameria, 2014). Berdasarkan dari latar belakang dan rumusan masalah pokok yang telah di kemukakan, maka tujuan dari penelitian ini adalah Untuk mengetahui mengenai penerapan sistem akuntansi manajemen terhadap pengendalian kualitas produk PT.Empat Saudara Manado.

\section{TINJAUAN PUSTAKA}

\subsection{Sistem Akuntansi Manajemen}

Sistem akuntansi manajemen adalah sistem yang mengumpulkan data operasional dan finansial, memprosesnya, menyimpannya dan melaporkannya kepada pengguna, yaitu para pekerja, manajer, dan eksekutif (Marina,2014). Dengan penjelasan diatas mengilhami Chenhall dan Morris merumuskan kharakteristik Sistem Informasi Akuntansi Manajemen yang bersifat broad scope, timeliness, aggregated, dan integrated menyatakan bahwa penggunaan informasi sistem akuntansi manajemen dapat membantu manajer dan organisasi untuk mengadopsi dan mengimplementasikan rencanarencana mereka dalam merespon lingkungan persaingan. Sistem akuntansi manajemen dilihat sebagai suatu sistem yang dapat memberikan informasi benchmarking dan monitoring dari informasi internal dan historis yang secara tradisional dihasilkan sistem akuntansi manajemen. Sistem akuntansi manajemen (SAM) merupakan sistem formal yang dirancang untuk menyediakan informasi bagi manajer. Perencanaan sistem akuntansi manajemen (Gusti Ayu,2014).

\subsection{Peranan Sistem Akuntansi Manajemen}

menyatakan informasi SAM dapat memudahkan pengguna (para manajer atau eksekutif) untuk mengontrol biaya, mengukur dan meningkatkan produktivitas, dan dapat pula memberikan dukungan terhadap proses produksi. berpendapat bahwa ada 3 komponen pengendalian system akuntansi manajemen (SAM) yaitu :

\section{a. Quality goals (Tujuan kualitas)}

Merupakan tujuan atau tingkat kinerja yang harus dicapai oleh suatu individu atau organisasi Tujuan atau target yang ditetapkan dengan jelas akan membuat individu atau pun kelompok mengerti apa yang harus dikerjakan. Individu atau kelompok tersebut dapat membuat perencanaan kerja sehingga kinerja mereka meningkat dan dapat mencapai tujuan perusahaan. Sasaran kualitas (quality goal) bisa dilihat sebagai tujuan atau tingkat kinerja 
yang individu atau organisasi harus capai. Suatu perusahaan harus memiliki sasaran yang ingin dicapai mengapa perusahaan tersebut didirikan.

\section{b. Quality feedback (Umpan balik kualitas)}

Merupakan informasi yang digunakan untuk mengevaluasi langkah-langkah yang dilakukan dalam melaksanakan suatu rencana. menyatakan bahwa feedback terhadap kinerja diperlukan untuk memungkinkan para karyawan menentukan hubungan antar perilaku mereka sendiri dan outcomes dari proses produksi.

Umpan balik merupakan hal yang sangat penting untuk dapat berkomunikasi secara efektif dengan karyawan. Karyawan akan terus memberikan umpan balik hanya jika anda mau dan mampu melakukan sesuatu dengan informasi yang anda peroleh.

\section{c. Quality-related incentives (Kualitas intensif)}

Merupakan sistem pengakuan dan sistem penghargaan untuk mengakui adanya perbaikan kualitas dari kelompok dan individu. Pengakuan dan pemberian penghargaan terhadap individu atau kelompok yang berprestasi/ yang memiliki kinerja baik akan sangat menjunjung kinerja kualitas produk yang diharapkan dapat menciptakan kondisi untuk memotivasi pekerja untuk mencapai hasil yang diinginkan.

\subsection{Pengendalian Kualitas ( Quality Control)}

Pengendalian Kualitas (Quality Control) merupakan suatu kegiatan untuk memelihara dan meningkatkan suatu produk melalui proses penelitian, pengembangan serta perancangan suatu produk yang bertujuan untuk memenuhi kepuasan konsumen. kegiatan ini dilakukan oleh team dari kualiti kontrol, akan tetapi tidak terlepas dari kerjasama seluruh karyawan beserta pimpinan dari sebuah perusahaan. kualitas suatu produk adalah "keadaan fisik, fungsi, dan sifat suatu produk bersangkutan yang dapat memenuhi selera dan kebutuhan konsumen dengan memuaskan sesuai dengan nilai uang yang telah dikeluarkan. (Ilham N.M,2012 dalam Lilia Pasca Riani,2016). Pengendalian dan pengawasan adalah: Kegiatan yang dilakukan untuk menjamin agar kegiatan produksi dan operasi yang dilaksanakan sesuai dengan apa yang direncanakan dan apabila terjadi penyimpangan, maka penyimpangan tersebut dapat dikoreksi sehingga apa yang diharapkan dapat tercapai. Tujuan dari pengendalian kualitas adalah:

1. Agar barang hasil produksi dapat mencapai standar kualitas yang telah ditetapkan.

2. Mengusahakan agar biaya inspeksi dapat menjadi sekecil mungkin.

3. Mengusahakan agar biaya desain dari produk dan proses dengan menggunakan kualitas produksi tertentu dapat menjadi sekecil mungkin.

4. Mengusahakan agar biaya produksi dapat menjadi serendah mungkin. Tujuan utama pengendalian kualitas adalah untuk mendapatkan jaminan bahwa kualitas produk atau jasa yang dihasilkan sesuai dengan standar kualitas yang telah ditetapkan dengan mengeluarkan biaya yang ekonomis atau serendah mungkin.

\section{METODE PENELITIAN}

\subsection{Jenis Penelitian}

Penelitian yang digunakan penulis yaitu bersifat deskriptif kualitatif, penelitian kualitatif adalah hasil dari menyimpulkan definisi yang diajukan para pakar dalam bukunya metode penelitian deskriptif kualitatif, (Lexy J.Moleong 2012:6) penelitian kualitatif adalah penelitian yang bermaksud untuk memahami tentang apa yang dialami oleh subjek penelitian, misalnya perilaku, persepsi, motivasi, tindakan, secara holistic, dan dengan cara deskripsi dalam bentuk kata-kata dan bahasa,suatu konteks khusus yang di alamiah dengan memanfaatkan berbagai metode ilmiah. 


\subsection{Tempat dan Waktu Penelitian}

Tempat yang dipilih dalam penelitian ini adalah PT Empat Saudara Manado ( Jalan sisingamangaraja No. 91 Kecamatan Wenang Kota Manado), pilihan lokasi ini dimaksudkan pada pertimbangan pegambilan sampel yang mudah dijangkau, waktu dalam penelitian ini dilakukan selama kurang lebih 1 minggu yaitu setelah usulan penelitian ini disetujui oleh pembimbing.

\subsection{Metode analisis}

Penelitian ini menggunakan metode analisis kualitatif. Penelitian deskriptif meliputi penilaian sikap atau pendapat terhadap individu, organisasi, keadaan, ataupun prosedur. Data deskriptif pada umumnya dikumpulkan melalui daftar pertanyaan dalam survei, wawancara, ataupun observasi (Indrawan dan Yaniawati, 2014: 56).

Metode yang digunakan dalam penelitian ini adalah, metode analisis deskriptif kualitatif, yaitu dengan cara menggambarkan kenyataan atau keadaan-keadaan atau suatu objek dalam bentuk uraian kalimat berdasarkan keterangan-keterangan dari pihak-pihak yang berhubungan langsung dengan penelitian ini.

Proses menganalisis dimulai dengan mengumpulkan data dan informasi dari pihak terkait di PT.Empat Saudara lalu mengelola data dan informasi yang diperoleh kemudian dari hasil analisis mengenai penerapan sistem akuntansi manajemen terhadap pegendalian kualitas produk tersebut dapat ditarik kesimpulan serta saran yang dianggap perlu untuk perbaikan dalam masalah yang dihadapi.

\section{HASIL ANALISIS DAN PEMBAHASAN \\ 4.1. Hasil analisis}

\section{Sistem Akuntansi Manajemen Pada Perusahaan}

Dalam mengendalikan kualitas produk, terdapat 3 komponen pengendalian SAM yaitu quality goals, quality feedback, dan quality incentive. Berikut ini akan diuraikan mengenai penerapan sistem akuntansi manajemen pada PT.Empat Saudara Manado. Ketiga komponen sistem akuntansi manajemen yang diterapkan di PT.Empat Saudara manado, adalah sebagai berikut :

\section{A. Tujuan kualitas (Quality Goals) Pada Perusahaan}

Perusahaan telah menempelkan papan-papan yang berisi informasi visi dan misi perusahaan di setiap sudut startegis ruang kerja seluruh karyawan. Hal ini dilakukan agar semua karyawan dari level atas sampai bawah dapat menjadikan pedoman kerja mereka dalam memproduksi barang. Pemasangan papan visi misi pada bagian produksi akan berpengaruh terhadap motivasi karyawan untuk tetap menjaga kualitas produknya sehingga bagian produksi memproduksi sesuai dengan standar kualitasnya. Dalam penerapan tujuan kualitas di PT.Empat Saudara, selalu mengutamakan kerjasama yang baik dari direktur sampai kepada karyawan, karna bertujuan untuk menciptakan kepercayaan yang baik supaya dalam setiap kegiatan operasional yang dilakukan perusahaan tidak terjadi kesalahan ataupun keterlambatan dalam memproduksi produk yang ada, dan juga agar menjaga mutu kualitas produk sampai ke tangan para konsumen.

\section{B. Umpan balik kualitas (Quality Feedback) Pada Perusahaan}

Perusahaan telah menerapkan jenis manajemen terbuka dalam proses pemberian feedback atas kinerja karyawan, yaitu karyawan dapat langsung mengetahui kesalahan dan segera memperbaikinya sehingga proses produksi dalam menghasilkan produk dapat dikendalikan dengan baik. dimana dalam tahap ini kerjasama sama antar karyawan sangat dibutuhkan agar setiap proses produksi yang terjadi dapat selalu dikontol dan diperbaiki, ikatan antara karyawan dan pimpinan perusahaan. Dalam tahap ini setiap kegiatan 
operasional di PT.Empat Saudara selalu mengawasi setiap kegiatan produksi mulai dari bagian gudang sampai pendistribusiannya, dimana kerjasama yang selalu menjadi tolak ukur perusahaan dalam setiap kegiatannya, perusahaan juga selalu mengutamakan keselamatan kerja kepada karyawannya seperti pemberian BPJS, supaya dalam pengerjaan yang ada tidak terjadi kesalahan ataupun keterlambatan produksi agar supaya pengerjaannya sesuai dengan ketepatan waktu yang telah ditetapkan oleh perusahaan.

\section{Kualitas insentif (Quality Insentive) Pada Perusahaan}

Perusahaan telah menerapkan quality incentives yaitu adanya ukuran kinerja keuangan dalam pemberian incentives yaitu meningkatnya omset penjualan sesuai dengan target yang telah ditentukan, adanya ukuran kinerja non-keuangan dalam pemberian incentives yaitu: pemberlakuan jam keterlambatan kerja, adanya catatan kehadiran dan adanya feedback dari customer. Dalam bagian ini PT.Empat Saudara selalu mengecek operasional keuangan perusahaan dan kualitas jam kerja karyawan yang ada, dalam operasional keuangan perusahaan selalu melakukan pembukuan setiap harinya dimana pemasukan atau pengeluaran keuangan perusahaan sesuai dengan kegiatan operasional pada hari itu juga. Dan dalam penerapan jam kerja di PT.Empat Saudara perusahaan melakukan sangsi jika terjadi keterlambatan kerja perusahaan melalukan pemotongan upah lembur, hal ini dilakukan perusahaan agar selalu mengutamakan kedisiplikan kerja kepada karyawannya supaya kegiatan operasional perusahaan tidak terganggu.

\section{Pegendalian Kualitas (Quality Control)}

Berdasarkan hasil penelitian PT.Empat Saudara Manado, perusahaan melakukan 3 tahap pegendalian kualitas produk yaitu :

a. Pengendalian Bahan Baku

Perusahaan selalu menjaga agar stok persedian bahan baku tidak berkurang, dimana perusahaan selalu melakukan pemesanan bahan baku dua bulan sebelumnya agar kegiatan produksi tidak terhenti, pemesanan bahan baku sendiri diambil perusahaan dari tambang garam di Surabaya. Juga menjaga agar persediaan bahan baku tidak terlalu besar atau berlebihan. Juga menjaga agar pembelian secara kecil-kecilan dapat dihindari karna akan berakibat biaya pemesanan terlalu besar.

b. Pengendalian Proses Produksi

Tujuan proses produksi perusahaan adalah untuk memenuhi kebutuhan pasar domestik, terlebih kebutuhan bahan pangan seperti garam sawi, dan menjaga kesinambungan perusahaan sebagai satu-satunya perusahaan garam di Sulawesi utara, dan meningkatkan lapangan usaha.

c. Pegendalian Produk Jadi

Perusahaan selalu melakukan pengecekan terhadap produk yang sudah siap di pasarkan dan bila produk yang didapat mengalami kerusakan atau kecatatan maka perusahaan melakukan tindakan perbaikan terhadap produk rusak yang masih bisa diperbaiki.

Dalam Pegendalian mutu kualitas PT.Empat Saudara manado selalu menggutamakan kualitas produk yang dihasilkan hingga sampai ke tangan konsumen, perusahaan selalu memantau setiap produk yang dihasilkan dan menganalisa terlebih dahulu apakah produk yang dihasilkan sudah siap untuk dipasarkan, dengan terlebih dahulu melakukan uji labotorium terlebih dahulu. Agar produk yang dihasilkan sesuai dengan standar yang diterapkan oleh BPOM (Badan Pengawas Obat dan Makanan). 


\subsection{Pembahasan}

Berdasarkan data yang telah ada dan yang dikumpulkan oleh peneliti,dapat dijelaskan bahwa penelitian analisis penerapan sistem akuntansi manajemen terhadap pengendalian kualitas produk di PT.Empat Saudara Manado sudah diterapkan oleh perusahaan. Dimana PT.Empat Saudara menerapkan 3 komponen sistem akuntansi manajemen antara lain :

1. Tujuan kualitas (Quality Goals) perusahaan agar selalu mencapai setiap target produksi yang ditetapkan juga menjaga kualitas produknya, dimana perusahaan selalu memberikan motivasi kepada karyawannya melalui visi dan misi yang dipegang oleh perusahaan, supaya tetap menjaga kualitas produk yang dihasilkan sesuai dengan standar kualitasnya.

2. Umpan balik Kualitas (Quality Feedback) perusahaan, dimana tujuannya agar dalam setiap kegiatan produksi bila terjadi kesalahan atau keterlambatan kerja, perusahaan langsung memperbaikinya sehingga proses produksi tidak terjadi keterlambatan dan dapat dikendalikan dengan baik. perusahaan juga selalu menggutamakan keselamatan kerja bagi karyawannya supaya tidak terjadi kesalahan dalam setiap kegiatan operasional yang sedang berlangsung.

3. Kualitas Insentif (Quality Insentive) ukuran kinerja perusahaan baik keuangan, pengaturan jam kerja sampai kepuasan konsumen sudah sangat baik, dalam kinerja keuanagan perusahan selalu melakukan pengecekan dan pembukuan setiap hari terhadap penjualan produknya, penerapan jam kerja kepada karyawan bila terjadi keterlambatan perusahaan hanya memotong pendapatan lemburnya saja, untuk kepuasan konsumen perusahaan selalu mendapatkan tanggapan yang positif untuk produk yang dihasilkan oleh perusahaan.

\section{KESIMPULAN DAN SARAN}

\subsection{Kesimpulan}

1. Sistem akuntansi manajemen terhadap pengendalian kualitas produk sudah diterapkan di PT.Empat Saudara Manado. dalam penerapannya sistem akuntansi manajemen di PT.Empat Saudara Manado telah menunjukan sebagai alat dalam pegendalian kualitas produk, dengan 3 metode sebagai landasan utama yang dijalankan yaitu tujuan kualitas (Quality Goals), umpan balik kualitas (Quality Feedback), dan kualitas insentif (Quality Insentive).

2. Penerapan sistem akuntansi manajemen terhadap pengendalian kualitas produk di PT.Empat Saudara Manado ternyata dapat membantu manajer untuk lebih siap dalam menghadapi permasalahan perusahaan dan mengendalikan kualitas produk untuk tetap menjaga kualitasnya agar tidak tersaingi oleh perusahaan lain, serta sistem akuntansi manajemen dapat menyajikan laporan kualitas yang berguna untuk mengembangkan kualitas produk.

\subsection{Saran}

Berdasarkan analisis terhadap PT.Empat Saudara Manado, diketahui bahwa Perusahaan sudah menerapkan sistem akuntansi manajemen dengan baik, perusahaan hanya perlu mempertahankannya sehingga dalam megontrol tiap bagian yang ada tidak terjadi kesalahan dalam setiap proses yang berjalan. Untuk meningkatkan kualitas kinerja karyawan/karyawati perusahaan, sebaiknya mengadakan pelatihan atau studi banding dengan perusahaan lain supaya dapat meningkatkan kualitas manajemen perusahaan. 


\section{DAFTAR PUSTAKA}

Alliah Siti, 2015 " Pengaruh Intensitas Kompetisi Pasar Terhadap Kinerja Manajer Ukm Melalui Informasi Sistem Akuntansi Manajemen''E-Jurnal Ekonomi dan Bisnis Universitas Udayana 4.08, ISSN : 2337-3067.

Ilham N.M. 2012. Analisis pengendalian kualitas produk dengan menggunakan

Statistical Processing Control (SPC) pada PT. AKADEMIKA; Vol. 14. No.1 Februari 2016 Analisis Pengendalian Kualitas Produk... 63 Bosowa Media Grafika (Tribun Timur). Skripsi. (Online). Makasar : Universitas Hasanuddin Makasar.

Indrawan, Poppy Yaniawati. 2014. Metodologi Penelitian. Penerbit Refika Aditama. Jakarta.

Lempas Yuwinda, 2014' Desentralisasi Dan Sistem Akuntansi Manajemen Terhadap Kinerja Manajer Pada Pt. Sinar Galesong Prima Manado', Jurnal EMBA, Vol.2 No.1 Maret 2014, Hal. 431-440.

Lingkiriwang Ferona Oktaviana, 2013, " Pengaruh Desentralisasi Sistem Akuntansi Manajemen Terhadap Kinerja Manajer Dealer Manado’. Universitas Sam Ratulangi Manado, Volume. 1, Nomor. 3, Juni 2013.

Moleong, Lexy J. 2012. Metodologi Penelitian Kualitatif, Bandung : Remaja Rosdakarya.

Riani Pasca Lilia,2016" analisis Pengendalian Kualitas Produk Tahu Putih (Studi Kasus Pada Home Industri Tahu Kasih Di Kabupaten Trenggalek), jurnal.stieimalang.ac.id, Universitas Nusantara PGRI Kediri, AKADEMIKA; Vol. 14. No.1 Februari 2016

Marina, A. 2014. Pengaruh Sistem Akuntansi Manajemen Terhadap Kinerja Manajerial dengan Ketidakpastian Lingkungan dan Desentralisasi Sebagai Variabel Moderating. JAI 5(2), Juli: Hal. 131-141.

Dhameria Vita, 2014"' Analisis Pengaruh Keunikan Desain Kemasan Produk. Kondusivitas Store Environment, Kualitas Display Produk Terhadap Keputusan Pembelian Impulsif (Studi Pada Pasaraya Sri Ratu Pemuda Semarang)', http.ejournal.undip.ac.id''Volume XIII, No. 1, Mei 2014, halaman $1-44$.

Wirjono Raino Endang. 2013. 'Hubungan Antara Sistem Akuntansi Manajemen dan Ketidakpastian Lingkungan yang dirasakan terhadap Kinerja Manajerial”. Vol.8 No.1 Januari 2013.

Ayu Gusti, 2014'’Pengaruh Karakteristik Informasi Sistem Akuntansi Manajemen Terhadap Kinerja Manajerial Studi Empiris pada PT Bank Perkreditan Rakyat di Kabupaten Tanah Datar,' Journal of Economic and Economic Education Vol.3 No.1 (94-99) 